KINGA BAUER

Uniwersytet Jagielloński

\title{
Kryzys finansowy a restrukturyzacja przedsiębiorstw w stanie upadłości
}

Instytucja upadłości odgrywa istotną rolę w gospodarce rynkowej. Upadłość przedsiębiorstw powszechnie postrzegana jest jako zjawisko negatywne, jednak w praktyce gospodarczej jest inaczej. Prawo upadłościowe i naprawcze ma za zadanie dbanie o interes publiczny poprzez ochronę uczestników gry rynkowej przed zagrożeniem ze strony nieefektywnego przedsiębiorcy. Istnienie niewypłacalnych przedsiębiorstw negatywnie wpływa na funkcjonowanie związanych z nimi organizacji. Brak możliwości regulowania zobowiązań przez potencjalnego bankruta może w konsekwencji doprowadzić do upadku jego wierzyciela. Ogłoszenie upadłości stanowi również ostrzeżenie przed nawiązywaniem kontaktów handlowych z nierentowną organizacją.

Problem upadłości przedsiębiorstw można rozpatrywać w aspekcie zarówno prawnym, jak i ekonomicznym. Z punktu widzenia ekonomii za bankruta uznaje się przedsiębiorstwo, które nie jest w stanie regulować terminowo swoich zobowiązań, a wartość majątku nie wystarcza na ich pokrycie, nawet jeśli nadal prowadzi ona swoją działalność. Z punktu widzenia prawnego upadłość następuje dopiero po ogłoszeniu jej przez sąd. Nie zawsze bankructwo w sensie ekonomicznym musi oznaczać upadłość w aspekcie prawnym, ale każda upadłość ogłoszona przez sąd oznacza bankructwo ekonomiczne (Prusak 2002).

Upadłość podmiotów gospodarczych wynika głównie z przyczyn ekonomicznych. Oczywiście, nie można pominąć wpływu przyczyn subiektywnych, tkwiących w sposobie zarządzania przedsiębiorstwem, w tym - przede wszystkim - w skłonności do ryzyka. Jednak podstawę do ogłoszenia upadłości stanowi nieregulowanie wymagalnych zobowiązań przez dłużnika. Dłużnika uznaje się również za niewypłacalnego (i tym samym można ogłosić jego upadłość) w sytuacji, gdy jego zobowiązania przekroczą wartość majątku, nawet jeśli na bieżąco reguluje on swoje zobowiązania.

Upadłość jest problemem społecznym, gdyż jej negatywne skutki dotykają znacznie większej liczby uczestników życia gospodarczego, aniżeli tylko samych właścicieli przedsiębiorstwa upadłego. Żaden podmiot gospodarczy nie działa w oderwaniu od otoczenia. Problemy finansowe jednej firmy dotykają wszystkich jej pracowników, dostawców, odbiorców, a także społeczeństwa, gdyż likwidacja przedsiębiorstwa oznacza pojawienie się na rynku pracy nowych bezrobotnych.

Jeśli sytuacja pracodawcy staje się krytyczna i sąd ogłosi jego upadłość, to ograniczona zostaje ochrona pracowników przysługująca im na mocy kodeksu pracy ${ }^{1}$ (Krawczyk 2009).

\footnotetext{
${ }^{1}$ Syndyk lub zarządca mogą rozwiązać każdą umowę o pracę bez względu na okres, na jaki ją zawarto. Skrócony także zostaje okres wypowiedzenia umowy o pracę, maksymalnie - dla umów zawartych na czas nieokreślony,
} 
Osoby pozbawione wynagrodzenia za pracę mniej wydają, przez co inne firmy muszą ograniczyć produkcję. Oznacza to, że w interesie państwa leży ograniczenie liczby bankrutujących podmiotów gospodarczych do tych jednostek, które nie są w stanie pokonać trudności w regulowaniu swoich zobowiązań.

Podkreślić należy, że choć upadłość przedsiębiorstw jest zjawiskiem, którego wyeliminowanie nie jest możliwe, to należy dążyć do tego, aby społeczne koszty tego procesu były minimalizowane. Oznacza to dążenie do możliwie sprawiedliwego rozłożenia strat między strony poszkodowane wskutek bankructwa.

W celu minimalizacji przenoszenia się trudności finansowych jednego przedsiębiorstwa na innych uczestników życia gospodarczego 1 października 2003 roku weszła w życie ustawa - Prawo upadłościowe i naprawcze. Ustawodawca rozróżnia w niej trzy możliwości działania w przypadku stwierdzenia problemów finansowych:

- postępowanie upadłościowe zmierzające do likwidacji majątku niewypłacalnego dłużnika,

- postępowanie upadłościowe z możliwością zawarcia układu,

- postępowanie naprawcze.

Dodatkowo, postępowanie upadłościowe zmierzające do zawarcia układu dzieli się na dwa różne sposoby postępowania, gdy upadły:

- został pozbawiony prawa zarządu swoim majątkiem,

- nie został pozbawiony prawa zarządu swoim majątkiem (ryc. 1).

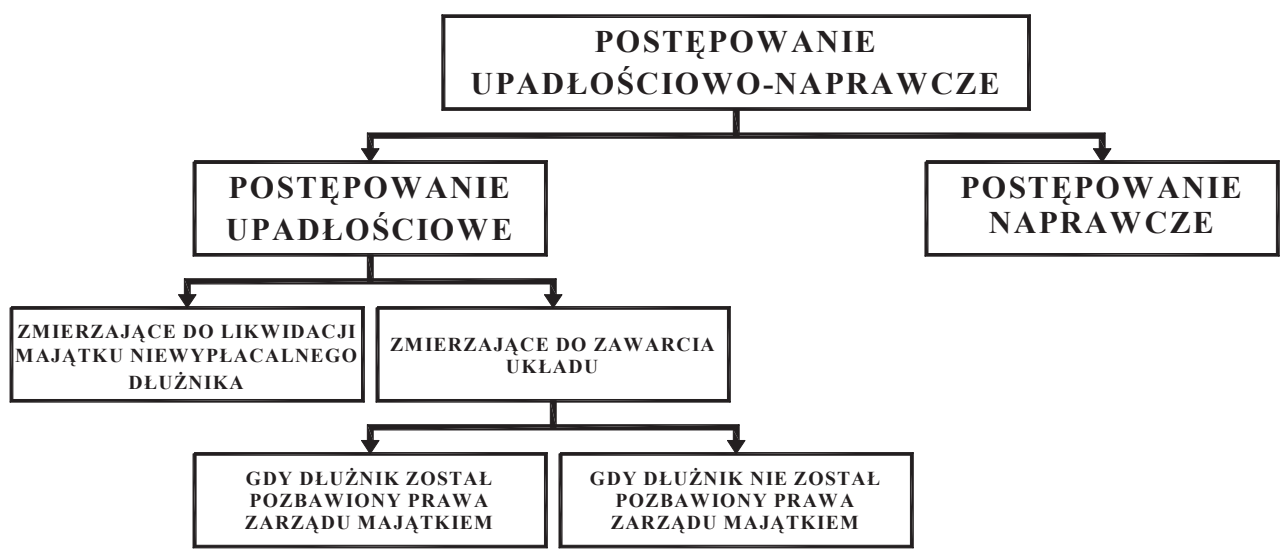

Ryc. 1. Klasyfikacja upadłości przedsiębiorstw

Źródło: Opracowanie własne

Ogłoszenie upadłości przedsiębiorstwa, zmierzające do likwidacji niewypłacalnego dłużnika, oznacza decyzje o zaniechaniu kontynuacji działalności. Upadłość prowadzącą do likwidacji majątku dłużnika ogłasza się w sytuacji, gdy brakuje podstaw do ogłoszenia upadłości z możliwością zawarcia układu. Powołany zostaje syndyk masy upadłości, który staje się kierownikiem jednostki upadłej. W przypadku tego rodzaju upadłości, jeśli nie zajdą

w których okres wypowiedzenia wynosiłby trzy miesiące - do jednego miesiąca. W tym trybie można również rozwiązać umowy o pracę pracowników będących na okresach ochronnych - usprawiedliwionych urlopach oraz w czasie ochronnym przed emeryturą (Krawczyk 2009). 
okoliczności zmieniające jej rodzaj², sprzedane zostaje przedsiębiorstwo (w całości lub, jeśli sprzedaż całego przedsiębiorstwa jest niemożliwa, w zorganizowanych częściach, sprzedawane są nieruchomości lub ruchomości), majątek firmy upadłej przechodzi na własność nabywcy, a następnie, ze środków uzyskanych ze sprzedaży, w kolejności określonej ustawą, zostają zaspokojeni wierzyciele.

Ogłoszenie upadłości nie musi jednak oznaczać końca istnienia firmy. Ogłoszenie przez sąd upadłości z możliwością zawarcia układu oznacza sytuację, w której przedsiębiorstwo - dłużnik może nadal kontynuować działalność gospodarczą. Ten rodzaj upadłości zostaje ogłoszony przez sąd, gdy w drodze układu wierzyciele zostaną zaspokojeni w wyższym stopniu niż w wyniku likwidacji majątku dłużnika (PUiN, art. 14, ust. 1).

W przypadku ogłoszenia upadłości z możliwością zawarcia układu powołany zostaje nadzorca sądowy lub, gdy odebrano zarząd majątkiem upadłemu, zarządca. Postępowanie upadłościowe zmierzające do zawarcia układu prowadzone jest w celu przywrócenia firmie zdolności do konkurowania na rynku. Dlatego konieczna jest restrukturyzacja przedsiębiorstwa. W sądzie składane są propozycje układowe, które muszą zawierać starannie przygotowany plan restrukturyzacji podmiotu upadłego. Propozycje układowe może złożyć upadły, nadzorca sądowy, zarządca lub wierzyciel. Propozycje te mogą być zgłoszone zarówno przed ogłoszeniem, jak i po ogłoszeniu upadłości przez sąd.

Propozycje układowe powinny określać jeden lub kilka sposobów restrukturyzacji zobowiązań wraz z uzasadnieniem. Propozycje mogą dotyczyć odroczenia spłaty zobowiązań, rozłożenia ich na raty, zmniejszenia sumy zobowiązań, zamianę wierzytelności - zależnie od formy prawnej przedsiębiorstwa dłużnika - na udziały lub akcje, zamianę, zmianę lub uchylenie prawa zabezpieczającego określoną wierzytelność (Działocha-Świetlikowska, Kowalski, Kućmin, Talarek 2003). Szczególny nacisk w planie układowym położony jest na restrukturyzację zobowiązań.

Kolejną możliwością odzyskania zdolności do konkurowania na rynku przez przedsiębiorstwo przechodzące kryzys jest postępowanie naprawcze. Jest ono nowością w polskim prawie. Ma na celu przywrócenie przedsiębiorstwu zdolności do konkurowania na rynku (Sawiłow 2004). Polskie przepisy o postępowaniu naprawczym są wzorowane na XI rozdziale amerykańskiego kodeksu upadłościowego.

Postępowanie naprawcze jest znacznie bardziej uproszczone od postępowania upadłościowego, jednak wymaga od dłużnika znacznego zaangażowania. Na dłużniku spoczywa obowiązek przeprowadzenia większości działań. Podstawą postępowania naprawczego jest przedłożenie przez zagrożonego niewypłacalnością przedsiębiorcę planu naprawczego.

Zgodnie $\mathrm{z}$ prawem plan naprawczy przedsiębiorstwa zagrożonego niewypłacalnością musi zawierać plan restrukturyzacji zobowiązań, majątku oraz zatrudnienia. Projekt restrukturyzacji majątku powinien informować, jaka część majątku zostanie sprzedana, wydzierżawiona lub wynajęta. Propozycje w zakresie restrukturyzacji zobowiązań mogą zawierać odroczenie wykonania zobowiązań, rozłożenie spłaty długów na raty, zmniejszenie sumy długów, zamianę długów na udziały lub akcje, zmianę, zamianę lub uchylenie prawa zabezpieczającego wierzytelność. Plan restrukturyzacji zatrudnienia powinien informować, jaki

\footnotetext{
${ }^{2}$ Ogłoszenie żadnego rodzaju upadłości nie jest decyzją ostateczną. Jeśli w trakcie trwania postępowania upadłościowego zmierzającego do likwidacji majątku niewypłacalnego dłużnika zostanie uprawdopodobnione, że postępowanie prowadzące do zawarcia układu w większym stopniu zaspokoi roszczenia wierzycieli, wówczas sąd zmieni rodzaj postępowania na postępowanie prowadzące do zawarcia układu.
} 
jest stan zatrudnienia, ile osób zostanie zwolnionych i jakie będą konsekwencje tych zmian (Brol 2003).

Dłużnik w postępowaniu naprawczym nie ma całkowitej samodzielności podejmowania decyzji i działania. W celu kontroli bieżącej działalności sąd ustanawia nadzorcę sądowego.

Istotną zmianą w zakresie regulacji prawnych odnośnie do ograniczania negatywnych skutków problemów finansowych przedsiębiorstw jest nowelizacja ustawy Prawo upadłościowe i naprawcze, która weszła w życie 2 maja 2009 roku. Jej celem było ułatwienie restrukturyzacji przedsiębiorstw i postępowania naprawczego (Kański 2009). Nowe przepisy pozwalają firmom zadłużonym w niewielkim stopniu (do 10\% wartości bilansowej przedsiębiorstwa), których opóźnienie w regulowaniu wymagalnych zobowiązań nie przekracza trzech miesięcy, prowadzenie za zgodą sądu postępowania naprawczego. W takich przypadkach sąd może oddalić wniosek o ogłoszenie upadłości, jednocześnie decydując o wszczęciu postępowania naprawczego.

Zmiany w zakresie regulacji prawnych mają pomóc w ratowaniu firm, które dotknęły jedynie przejściowe problemy finansowe. Jeśli przedsiębiorstwa będą w stanie w wyższym stopniu zaspokoić roszczenia wierzycieli dzięki postępowaniu naprawczemu lub prowadzącemu do zawarcia układu z wierzycielami, sąd nie pozbawi ich możliwości kontynuacji działalności gospodarczej.

Problem upadłości nabiera szczególnego znaczenia w czasach światowego kryzysu gospodarczego. „Kryzysy finansowe nie są zjawiskiem nowym. Stanowią one bezpośrednią reakcję na błędy popełniane przez człowieka i świadczą o tym, że mechanizmy rynkowe działają bardzo skutecznie" (Surdykowska 2009). Obecny kryzys finansowy trwa od 2007 roku. Jednak jego nasilenie wiąże się z upadkiem czwartego co do wielkości banku w USA - Lehman Brothers. Oficjalne ogłoszenie bankructwa banku, w połowie września 2008 roku, spowodowało kolejne spadki na GPW. 15 września 2008 roku WIG20 znalazł się poniżej najniższego punktu zapoczątkowanej w lipcu 2007 r. bessy (Satalecki 2008).

Kryzys objawia się znaczącym pogorszeniem gospodarki. Nasilanie się zjawiska upadłości jest związane z nasilaniem się kryzysu gospodarczego. Naturalnym zjawiskiem w czasach kryzysu są upadki banków i innych instytucji finansowych, bankructwa dużych i małych przedsiębiorstw oraz osób prywatnych. Tym samym spada zatrudnienie, rośnie bezrobocie.

W Polsce przewidywano, iż w związku ze spowolnieniem gospodarczym, w 2009 roku upadnie około 900 przedsiębiorstw, czyli ponad dwa razy więcej niż w ubiegłym roku (Jaworski 2007). Wbrew początkowym oczekiwaniom, w ciągu pierwszych trzech kwartałów tego roku upadło 497 firm. Sytuacja w zakresie ilości ogłaszanych upadłości była więc korzystniejsza niż zakładano, jednak duża ilość bankructw była o 57\% większa niż w tym samym okresie 2008 roku.

Z badań przeprowadzonych w Sądzie Rejonowym dla Krakowa - Śródmieścia w Krakowie w Wydziale VIII Gospodarczym dla spraw upadłościowych i naprawczych ${ }^{3}$ wynika, iż na tym obszarze kraju w roku 2009 tendencja w zakresie ogłaszanych upadłości była podobna. W pierwszych trzech kwartałach ogłoszono 35 upadłości, czyli przeszło 7\%

\footnotetext{
${ }^{3}$ Badania zostały przeprowadzone w Sądzie Rejonowym dla Krakowa - Śródmieścia w Krakowie w Wydziale VIII Gospodarczym do spraw upadłościowych i naprawczych w okresie od 1 VI 2006 do 31 X 2009. Obszar Sądu obejmuje dzielnicę Kraków - Śródmieście oraz gminy Iwanowice, Michałowice, Skałę, Słomniki i Słuszową. Badania objęły analizę dokumentacji procesów upadłościowych i naprawczych (case study) oraz danych statystycznych wszystkich spraw prowadzonych przez ww. wydział.
} 
upadłości ogłoszonych w całym kraju (do końca października 2009 roku - 37). W latach 2004-2009 była to najwyższa liczba ogłoszonych upadłości (ryc. 2).

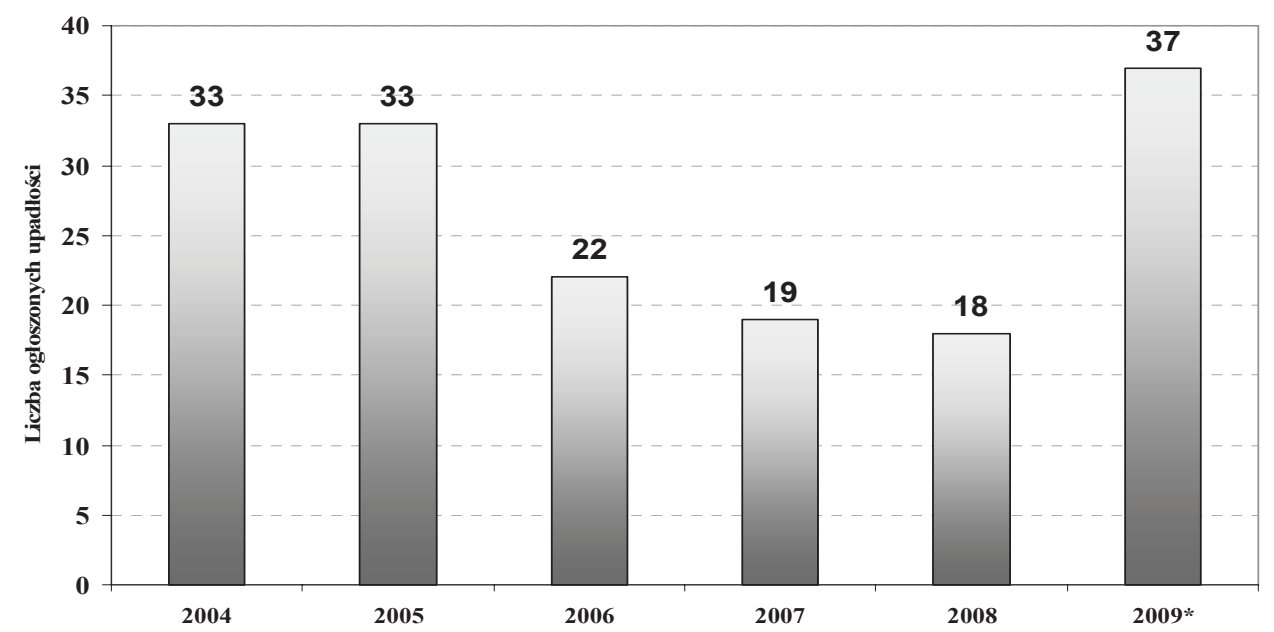

*od stycznia do października 2009 r.

Ryc. 2. Liczba ogłoszonych upadłości w Krakowie - Śródmieściu w latach 2004-2009 - dane roczne Źródło: Opracowanie własne na podstawie danych z Sądu Rejonowego dla Krakowa - Śródmieścia w Krakowie

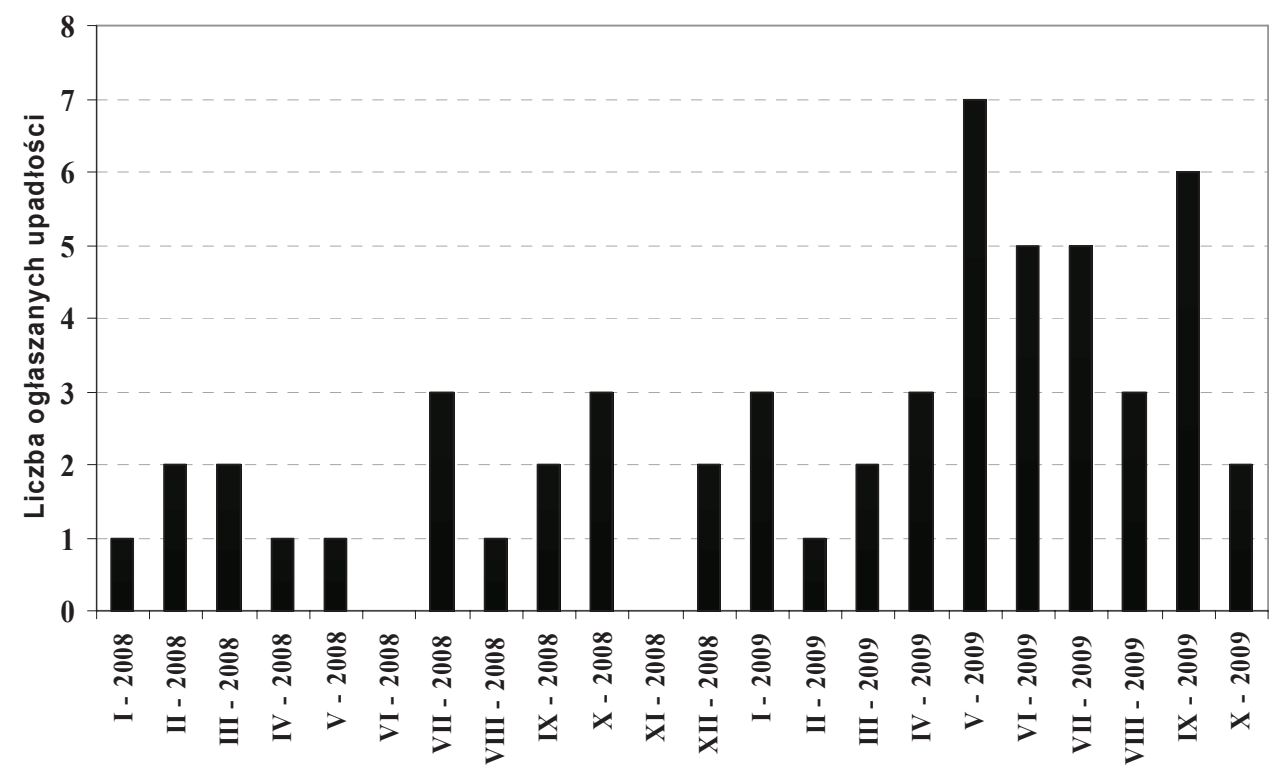

Ryc. 3. Liczba ogłaszanych upadłości w Krakowie - Śródmieściu w okresie: styczeń 2008 - październik 2009 r.

Źródło: Opracowanie własne na podstawie danych z Sądu Rejonowego dla Krakowa - Śródmieścia w Krakowie 
Do końca października nie zaobserwowano jednak tendencji wyhamowującej w zakresie składanych wniosków i ogłaszanych upadłości. Jedynie październik był na tym obszarze kraju wyjątkowo korzystny w zakresie ogłaszanych upadłości - ogłoszono jedynie dwie upadłości (ryc. 3). Jednak w tym samym czasie ponownie wzrosła liczba składanych wniosków o ogłoszenie upadłości, co może wpłynąć na wzrost liczby upadłości w kolejnych miesiącach (ryc. 4).

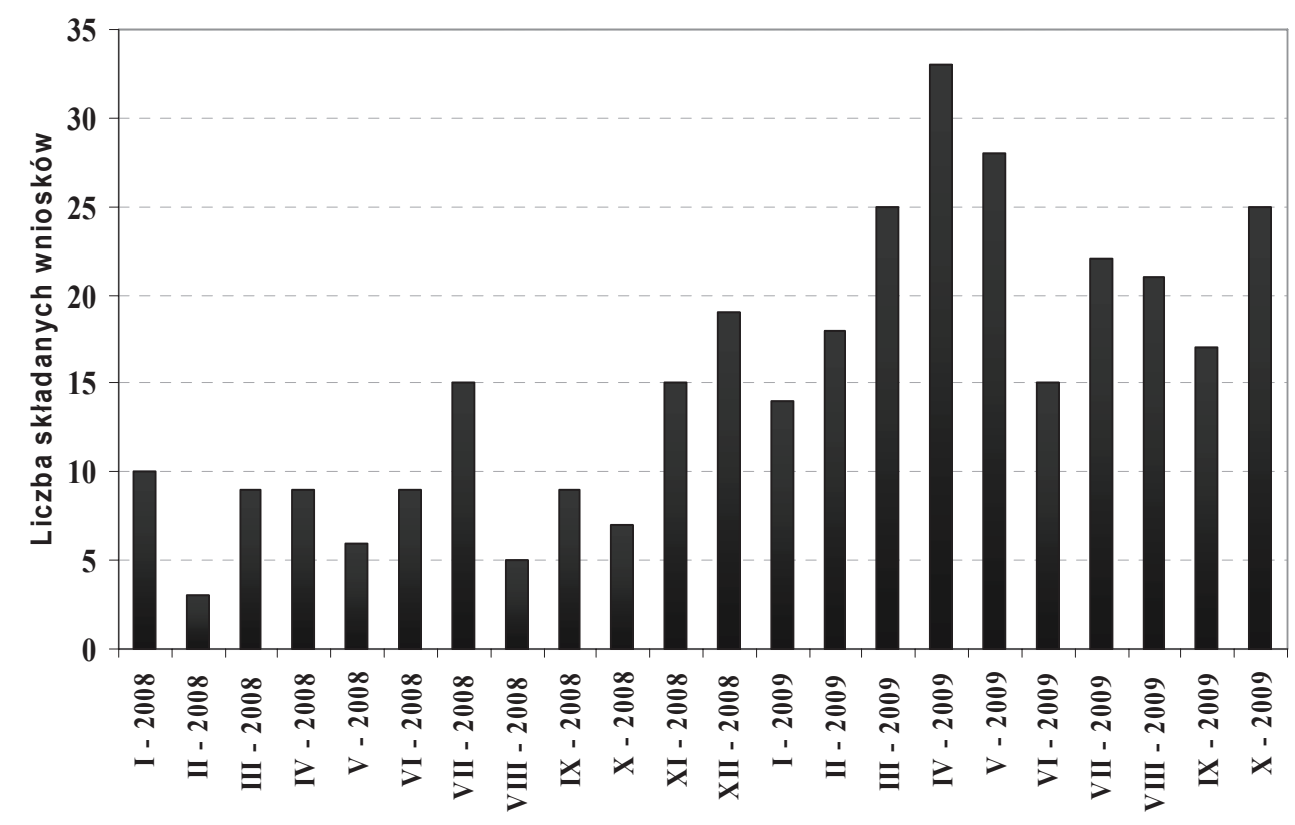

Ryc. 4. Liczba składanych wniosków o ogłoszenie upadłości w Krakowie - Śródmieściu w okresie: styczeń 2008 - październik 2009 r.

Źródło: Opracowanie własne na podstawie danych z Sądu Rejonowego dla Krakowa - Śródmieścia w Krakowie

Kryzys wpływa również na rodzaj prowadzonych postępowań upadłościowych. W okresie od 1 stycznia 2004 roku do 30 czerwca 2009 roku upadłości zmierzające do zawarcia układu stanowiły prawie $38 \%$ całości postępowań upadłościowych. Jednak w pierwszym półroczu 2009 roku ich udział w ogólnej sumie postępowań spadł do 19\%. Takie zjawisko może świadczyć o tym, iż kondycja przedsiębiorstw w roku 2009 jest gorsza niż w poprzednich latach.

Powszechnie panuje opinia, iż przepisy dotyczące postępowania naprawczego są przepisami „martwymi”. W praktyce stosowane jest ono sporadycznie, gdyż rygory formalne narzucone w 2003 roku stanowią poważną barierę dla przedsiębiorstw chcących wdrażać proces naprawczy (Domagalski 2008). Od początku 2004 roku do października 2009 roku w Sądzie Rejonowym dla Krakowa - Śródmieścia w Krakowie zostało złożonych 15 oświadczeń o wszczęciu postępowania naprawczego. Jednak w każdym przypadku Sąd zakazał wszczęcia takiego postępowania. Głównymi przyczynami były błędy formalne, pomyłki i zaniedbania w przedkładanej w sądzie dokumentacji, szczególnie w zakresie szacunkowej wyceny majątku firmy. 
Ostatnia nowelizacja Prawa upadłościowego i naprawczego nie zmieniła tego stanu. W roku 2009, mimo nowelizacji przepisów prawa, ani jedno oświadczenie nie zostało złożone w Sądzie Rejonowym dla Krakowa - Śródmieścia. Sąd nie skorzystał również z prawa oddalenia wniosku o ogłoszenie upadłości i równocześnie zezwolenie na wszczęcie postępowania naprawczego (ryc. 5).

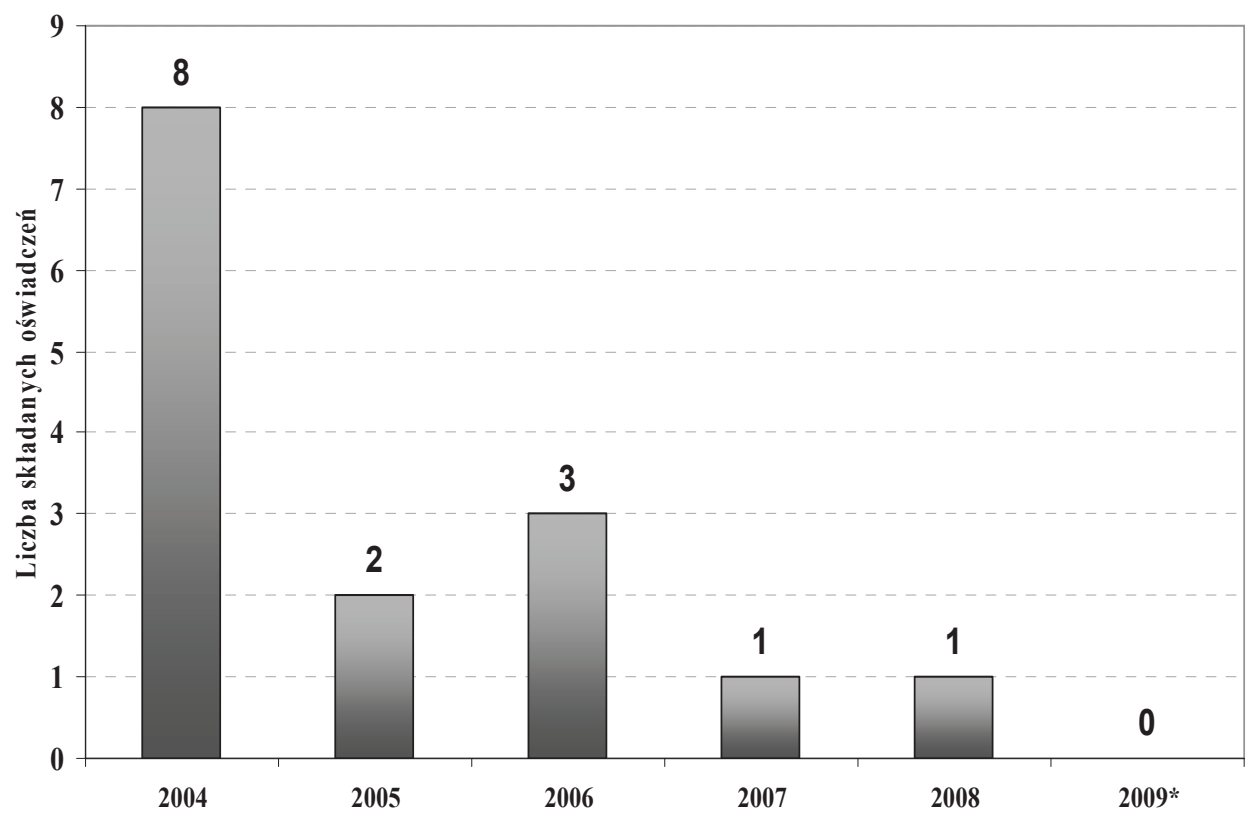

*od stycznia do października 2009 r.

Ryc. 5. Liczba składanych oświadczeń o wszczęciu postępowania naprawczego w Krakowie - Śródmieściu w latach: 2004-2009

Źródło: Opracowanie własne na podstawie danych z Sądu Rejonowego dla Krakowa - Śródmieścia w Krakowie

Problem upadłości w czasach kryzysu dotyczy zwłaszcza niektórych branż. Największa liczba upadłości była ogłaszana w przetwórstwie przemysłowym, w handlu i budownictwie (Więcław 2009).

Cechą charakterystyczną obecnego kryzysu jest niepokojące zjawisko problemów finansowych dużych, do niedawna silnych kapitałowo firm. Kłopoty finansowe mają największe firmy odzieżowe, maszynowe, meblarskie i inne. W 2009 roku upadłość ogłosiła jedna z najstarszych spółek publicznych w Polsce - Huta Szkła Krosno. Problemy finansowe dotknęły również Swarzędz, Monnari, Galerię Centrum, Odlewnie Polskie i Pronox. Równie wysoką liczbę upadłości na GPW notowano ostatnio w 2002 roku, w związku z kryzysem światowej gospodarki po 11 września 2001 roku (Iskra 2009).

Spowolnienie polskiej gospodarki w czasach światowego kryzysu gospodarczego spowodowało znaczny wzrost liczby upadłości przedsiębiorstw. Podkreślić należy, że Prawo upadłościowe i naprawcze narzuca przedsiębiorstwom w stanie upadłości lub wdrażającym proces naprawczy pewne minimum w zakresie restrukturyzacji, a mianowicie przedstawie- 
nie takich propozycji układowych, które zaspokoją roszczenia wierzycieli w jak największym, najlepiej $100 \%$ stopniu. Jeśli przedsiębiorstwa chcą przetrwać sytuację kryzysową, muszą opracować plan restrukturyzacji naprawczej przedsiębiorstwa - zarówno wymaganej przez prawo restrukturyzacji zobowiązań, majątku, zatrudnienia, jak również podyktowanej racjonalnym zarządzaniem strategii działania. Są to działania stabilizujące, których celem jest przywrócenie przedsiębiorstwu utraconej sprawności. Konieczne jest także dostosowanie się do otoczenia, w którym działa przedsiębiorstwo.

Zakończenie postępowania upadłościowego zmierzającego do zawarcia układu oraz postępowania naprawczego oznacza, iż firma powraca na rynek. Jeśli ma przetrwać, zwłaszcza w trudnych czasach spowolnienia gospodarczego, niezbędne jest dokonanie gruntownych zmian w przedsiębiorstwie, aby nie powtórzyła się sytuacja kryzysowa.

Restrukturyzacja oznacza przeprowadzenie zmian w przedsiębiorstwie, których zadaniem jest usprawnienie jego działalności. Obejmuje ona czynności mające na celu przetrwanie firmy w krótkim czasie, a w dłuższej perspektywie jej rozwój. Z punktu widzenia sposobu przeprowadzenia restrukturyzacji wyróżnić można restrukturyzację naprawczą i rozwojową (Nowak 2009). Podkreślić jednak należy, że punktem wyjścia dla przedsiębiorstw przeżywających kryzys jest restrukturyzacja naprawcza.

„Restrukturyzacja naprawcza, to dziś najpopularniejsza forma walki ze skutkami kryzysu gospodarczego w setkach tysięcy firm, nie tylko w Europie, ale i na świecie. Głównym jej celem jest wdrożenie zmian, które mają doprowadzić do naprawy przedsiębiorstwa oraz ustabilizowania jego sytuacji bilansowej” (Anam 2009).

Restrukturyzacja może być przeprowadzana w każdej fazie cyklu życia przedsiębiorstwa. Zmiany majątkowe, organizacyjne i ekonomiczne powinny mieć miejsce zawsze, gdy zachodzi taka konieczność. Fundamentalne znaczenie dla przetrwania firm oraz osiagnięcia odpowiednio wysokich wskaźników w czasach kryzysu gospodarczego ma zachowanie płynności i rentowności. Przedsiębiorstwa muszą dbać nie tylko o dodatni wynik finansowy, ale również o zmniejszenie ryzyka dalszej działalności gospodarczej. Tym celom powinny być podporządkowane działania osób zarządzających przedsiębiorstwem, również w stanie upadłości zmierzającej do zawarcia układu. Działania takie będą łatwiejsze w przypadkach, gdy sąd pozostawi zarząd majątkiem jednostki upadłej w rękach dłużnika. W jego interesie leży dbanie nie tylko o zapewnienie firmie możliwości zaspokojenia roszczeń wierzycieli, lecz również o wprowadzenie zmian, które pozwolą jej - po wykonaniu układu - być konkurencyjnymi na rynku.

Działanie mające na celu pokrycie wierzytelności upadłej firmy oraz jej przetrwanie po zakończonym procesie upadłościowym leży nie tylko $\mathrm{w}$ interesie przedsiębiorcy, ale i w interesie społecznym. Dlatego również w przypadku pozbawienia dłużnika prawa zarządu majątkiem zarządca i sąd powinni stać na straży efektywności działania firm upadłych. W tym przypadku efektywność będzie rozumiana przede wszystkim jako minimalizacja strat i ich w miarę możliwości sprawiedliwe rozłożenie pomiędzy strony poszkodowane w wyniku upadłości. Konieczne jest również branie pod uwagę przyszłości przedsiębiorstwa w stanie upadłości zmierzającej do zawarcia układu (lub wdrażającego proces naprawczy) i stosowanie tych samych zasad działania co w przypadku innych przedsiębiorstw kontynuujących działalność gospodarczą. W tym celu konieczne wydają się gruntowne zmiany wewnątrz przedsiębiorstwa oraz wykorzystanie rachunków ekonomicznych jako podstawy jego działalności. 
Kryzysy gospodarcze są przyczyną problemów finansowych wielu przedsiębiorstw. Mogą jednak stanowić cenny impuls do przeprowadzenia zmian, dalszego rozwoju przedsiębiorstwa, a w konsekwencji wzmocnienia jego pozycji rynkowej.

\section{Literatura}

Anam R., http://www.egospodarka.pl/article/articleprint/38646/-1/11

Bauer K., 2009, Zarzadzanie informacjami w procesie upadlościowym przedsiębiorstw, Wydawnictwo Uniwersytetu Jagiellońskiego, Kraków

Brol J., 2003, Nowe prawo upadtościowe i naprawcze (4) Postępowanie naprawcze, „Rachunkowość”, nr 12

Domagalski M., 2008, Łatwiejsza obrona przed bankructwem, „Rzeczpospolita”, nr 123 (8024)

Działocha-Świetlikowska A., Kowalski A., Kućmin B., Talarek U., 2003, Upadtość i likwidacja przedsiębiorstw osób fizycznych i spółek osobowych $w$ aspekcie prawnym i praktyce podatkowej oraz księgowej, Difin, Warszawa

Iskra J., 2009, Najwięcej bankructw od siedmiu lat, „Gazeta Prawna”, nr 109

Jaworski M., 2009, W tym roku może upaść aż 900 przedsiębiorstw, „Gazeta Prawna”, nr 107

Kański T., 2009, Czy znowelizowane przepisy o upadłości usprawnia postępowanie naprawcze, „Gazeta Prawna", nr 95

Krawczyk J., 2009, Upadłość pozwala zwalniać wszystkich, „Rzeczpospolita”, 14 X

Nowak E., 2009, Zaawansowana rachunkowość zarzqdcza, Polskie Wydawnictwo Ekonomiczne, Warszawa

Prusak B., 2002, Upadtość - mit klęski, czy szansa na odrodzenie, http://www.zie.pg.gda.pl/ pb/uko. pdf

Satalecki P., 2008., Bankructwo Lehman Brothers dotuje GPW, http://www.money.pl//gielda/komentarze/artykul/bankructwo;lehman;brothers;doluje;gwp,28,0,370460.html

Sawiłow J., 2004, Postępowanie naprawcze jako nowa, sui generis instytucja prawa upadłościowego. Wybrane zagadnienia, „Prawo Spółek”, nr 1

Surdykowska S., 2009, Kryzysy finansowe a wiarygodność sprawozdań finansowych, [w:] Problemy wspótczesnej rachunkowości, pod red. nauk. pracowników Katedry Rachunkowości SGH, Szkoła Główna Handlowa w Warszawie, Warszawa

Ustawa z dnia 28 lutego 2003, Prawo upadłościowe i naprawcze, Dz. U. z 2003, nr 60, poz. 535

Więcław E., 2009, Najsłabsi nie przetrwali kryzysu, „Rzeczpospolita”, 2 X

\section{Financial crisis and bankrupt companies restructuring}

Bankruptcy of enterprises is generally recognized as a negative phenomenon. In practice, the institution of bankruptcy aims at protecting interests of the market game participants. It eliminates from the market the enterprises which are not able to conduct their activities effectively. This way, it also protects other entities from establishing relationships with a company which is unable to rival its competitors.

The article concerns problems of insolvent and bankrupt companies in the financial time crisis. It brings up theoretical and practical aspects of this issue.

Some enterprises are not able to survive as before in the period of economic crisis. In 2009, the number of insolvent and bankrupt companies grew up rapidly. Restructuring can be a response to a crisis or major change in the business, such as insolvency and bankruptcy.

The article focuses on the results of basic and scientific research conducted at the Law Court in Cracow at the Department of Insolvency and Bankruptcy. 


\section{Dr Kinga Bauer}

Uniwersytet Jagielloński

Instytut Ekonomii i Zarządzania

Katedra Rachunkowości Międzynarodowej

e-mail: kinga.bauer@uj.edu.pl 